\title{
Information Sources, Knowledge and Practice Towards HIV/ Hepatitis B Co-Infection In Lagos, Nigeria
}

\author{
Evaristus Adesina ${ }^{1}$, Oladokun Omojola ${ }^{2}$, David Imhonopi ${ }^{3}$, Babatunde Adeyeye ${ }^{4}$, \\ Charity Ben-Enukora ${ }^{5}$, Scholastica Anake ${ }^{6}$ \\ Department of Mass Communication 123456, Covenant University, Ota, Nigeria
}

Received: December 27, 2020. Revised: June 29, 2021. Accepted: July 15, 2021. Published: July 20, 2021.

\begin{abstract}
Attaining the objective of healthy lives and wellbeing Sustainable Development Goal 3 is hinged on effective health communication. This study investigates the information source usage, knowledge, attitude and practices of 200 dwellers of Lagos, Nigeria towards HIV/HBV co-infection. In this cross-sectional study, the simple random sampling method was employed in selecting 200 participants in the most populated local government in Lagos state, Nigeria. Questionnaire instrument was created, to elicit responses on four major areas: uses of information sources, knowledge, attitude, health practice towards HIV/HBV co-infection. Descriptive statistical data in percentages and cross-tabulations were employed. The study indicated that $60.4 \%$ of the respondents source for information on HIV/HBV co-infection on television. Furthermore, while $60 \%$ noted the coinfection is caused by a virus $48.5 \%$ declared that the fear of death will be their main concern if they were diagnosed with the co-infection. The result further reveals that only $\mathbf{2 6 . 8 \%}$ of the sampled respondents have been tested for the co-infection in Lagos State. The study concludes that there is need for the creation of preventive information campaigns for awareness in order to mitigate the rising cases of $\mathrm{HIV} / \mathrm{HBV}$ co-infection as well as influence persons towards healthy practices. The insight from this study would further provide a focal point of direction to government as well as non-governmental organisations working on HIV/HBV co-infection in Nigeria.
\end{abstract}

\section{INTRODUCTION}

The world has recorded several infectious diseases which serve as threats to public health and safety of human lives. When public health is endangered, humanity is threatened. Therefore, improved health and healthy lifestyle have overtime, become a core focus of global societies. The United Nations, in a bid to reduce the prevalence of these harmful diseases, set the SDG 3 attainment goal by year 2030. The targets of this goal specifically include ending epidemic diseases such as HIV, AIDS and hepatitis [1].

Human Immunodeficiency Virus and Hepatitis B have been regarded as deadly diseases, having high morbidity and death rates beyond mono infections [2]. The World Health Organization WHO [3], explains Hepatitis B as a virus causing infection (Hepatitis B Virus), that affects the liver, leading to high-risk of death through cirrhosis and liver cancer. It has been recorded that approximately 2 billion people

globally has a serologic proof hepatitis B infection. This deadly disease has transmission routes from mother to foetus, contact with infected blood and body fluids, unprotected sex with an infected partner, using sharp objects such as razorblades, needles, syringes, and other equipment which are unsterilized and have been exposed to infected individuals [4]. Statistics show that as at 2015, there were approximately 257 million people living with chronic effects of this virus [5], while there was an estimate of 887,000 deaths from hepatitis B in the same year [6].

Human Immunodeficiency Virus is a worrying global disease, as 33 million people have died, and during the end of 2019, it was estimated that there are 38 million 
people currently living with HIV (WHO, 2020b). HIV has been known to weaken the immune system by attacking the infection-fighting CD4 cells, making the body more susceptible to other viruses and infections. Though there are treatment and cure packages for HIV victims to enable them to live long and healthy lifestyles, not everyone has access to these services and packages. Therefore, leading to 690,000 deaths relating to HIV, and 1.7 million new cases (WHO, 2020b).

Even though HBV is noted to be a hundred times more transmissible than HIV [7-9], however both diseases have similar infectious routes [10]. Conditions associated with HBV have become one of the mortality causing factor in HIV infected people [11]. The World Health Organization (2020a), stated that about 2.7 million HBV-positive individuals, are also HIV-positive. The prevalence of HIV/HBV coinfection globally is $7.4 \%$. In mitigating this effect, the World Health Organization suggested the testing of hepatitis B surface antigen (HBsAg) in HIV infected patients[12, 13]. Since there is Hepatitis B vaccine, it is recommended that HIV-positive individuals get this vaccination, to avoid further infection with HBV.

These diseases are endemic in regions such as SubSharan Africa, Southeast Asia and Western Pacific. According to WHO report on regions with the greatest endemic rate, Africa has $6.1 \%$, equivalent to 60 million people while Western Pacific Region has 6.2\% (115 million people) [3]. Consequently, Africa shares almost two-third of the global new HIV infections [14, 15]. The prevalence of these two diseases in Africa increases the possibility of an individual to have HIV/HBV co-infection. Thus, the necessity for information and awareness mobilization campaigns and programs.
Information is a fundamental resource to human existence and survival. Majorly, information engenders knowledge, facilitates the positive attitude as well as improves practices towards health issues. Various sources of information have been utilized to provide certain health communication needs to certain groups of people, based on demographics and psychographics. Information sources have been noted as an essential component in public health knowledge [16-20]. Governmental and non-governmental organizations dealing with public health issues have leveraged on these information source. Historically, the most sought after source of health information is the interpersonal means especially from health physicians [21-24]. While the traditional media such as television, radio, newspapers, magazines and billboards have also been massively utilized, the internet mediated platforms are gaining grounds as a major means of health information.

While researches have examined HIV/HBV coinfections prevalence rate in Nigeria [25-28], there is however a paucity of studies on information source usage, knowledge, attitude and practice of citizens towards the co-infection. This study aims at filling this gap by assessesing the use of information source, knowledge, attitude and practice of residents of Lagos, Southwest Nigeria towards HIV/HBV co-infections

\section{METHODOLOGY}

Quantitative research method of survey was employed in this study to assess the use of information sources, knowledge, attitude and practice of the HIV/HBV coinfection among residents of Lagos, Nigeria. The choice of Lagos is predicated on its vastly heterogeneous geographical nature, covering ethnic groups from almost all over Nigeria, in addition it is the home to major international populations [29, 30]. 


\section{DATA MEASUREMENTS}

The instrument of questionnaire was created, to elicit responses on five major areas: uses of information sources, knowledge, attitude, health practice as well as demographic characteristics. Element of the health belief model were also captured in the instrument.

\section{STUDY PARTICIPANTS}

The simple random sampling technique was used in selecting the 200 participants residing in Alimosho Local Government of Lagos State. The local government has been noted to be the most populated in Lagos state with an estimate 1,319,571 inhabitants [31].

\section{DATA ANALYSIS}

Information sources, knowledge, attitudes practices towards HIV/HBV co-infection were analysed using descriptive statistical data, expressed in percentages and cross-tabulations.

\section{RESULT}

\section{Sociodemographic characteristics}

Two hundred respondents participated in the study with $58 \%$ representing the male gender and $41.5 \%$ females. Respondents within the age group of 18-25 representing $29.5 \%$ constituted the largest participants, followed by 25-35 (28\%), 36-45 (20\%), below 18 (12.6\%), 46-55 (7.4\%) and 1.7\% in the age range of 55 and above. Furthermore, students (36.2\%), white collar job (25.4) traders (13\%), unemployed $(11.9 \%)$ made up the occupation category. In addition, the marital status classification of respondents are $56.5 \%$ singles, $35 \%$ married and $6.2 \%$ single parents.

The result in Table 2 shows respondents' usage of information sources for HIV/HBV co-infection. From

\begin{tabular}{lr}
\hline \multicolumn{1}{c}{ Table 1 } & $\begin{array}{c}\text { Demographic characteristics of } \\
\text { respondents }\end{array}$ \\
\hline Gender & \% \\
Male & \\
Female & 58.4 \\
Total & 41.6 \\
Age group & 100.0 \\
Below 18 & \\
18-25 & 12.6 \\
26-35 & 29.7 \\
36-45 & 28.0 \\
46-55 & 20.6 \\
55 and Above & 7.4 \\
Total & 1.7 \\
Occupation & 100.0 \\
Trader & \\
Artisan & 13.0 \\
White collar job & 5.6 \\
Student & 25.4 \\
Unemployed & 36.2 \\
Others & 11.9 \\
Total & 7.9 \\
Marital Status & 100.0 \\
Single & \\
Married & 56.5 \\
Single parent & 35.0 \\
Others & 6.2 \\
Total & 2.3 \\
\hline table, while 51.4\% of the respondents strongly & 100.0 \\
\hline
\end{tabular}

the table, while $51.4 \%$ of the respondents strongly agreed and agreed to use radio channel, $41.6 \%$ noted that they do not use it. In the television category, majority of the respondent totaling $60.4 \%$ agreed to be using television in getting messages on the coinfection. For the newspaper channel, $46.7 \%$ noted to be employing the channel for information, on the other hand, $42.9 \%$ were in disagreement. For the channel sources of leaflet, pamphlet, brochure, flyers and catalogue recorded $54 \%$ of the respondents disclosed

they do not seek information of the disease from them, while $35 \%$ reacted in the positive. Respondents who seek information on the co-infection from the internet mediated sources are $49.9 \%$. A total of $46.9 \%$ stated they seek information on the disease from health workers, while $40.3 \%$ affirmed in the negative. The source of seminar/workshop/conference did not attract much attention, as $53.2 \%$ stated they do not utilize 
these platforms. Generally, from all the information sources, about $60 \%$ of the respondent employ the television source for their messages on HIV/HBV coinfection in Lagos state.

Table 2

Respondents' usage of information sources for HIV/HBV Co-infection

\begin{tabular}{lcccccccc}
\hline Information Sources & $\begin{array}{c}\text { Strongly } \\
\text { agree } \\
(\mathbf{\%})\end{array}$ & $\begin{array}{c}\text { Agree } \\
(\mathbf{\%})\end{array}$ & $\begin{array}{c}\text { Undecided } \\
(\mathbf{\%})\end{array}$ & $\begin{array}{c}\text { Disagree } \\
(\mathbf{\%})\end{array}$ & $\begin{array}{c}\text { Strongly } \\
\text { disagree } \\
(\mathbf{\%})\end{array}$ & $\begin{array}{c}\text { Total } \\
\mathbf{\%}(\mathbf{n = 2 0 0})\end{array}$ & Mean & SD \\
Radio & 22.2 & 29.2 & 7.0 & 14.6 & 27.0 & 100 & 2.95 & 1.554 \\
Television & 28.3 & 32.1 & 8.6 & 13.4 & 17.6 & 100 & 2.6 & 1.464 \\
Newspaper & 21.7 & 25.0 & 10.3 & 20.1 & $22.8)$ & 100 & 2.97 & 1.498 \\
$\begin{array}{l}\text { Leaflets/pamphlet/brochure/ } \\
\text { flyer/catalogue }\end{array}$ & 15.6 & 19.4 & 10.8 & 22.7 & 31.3 & 100 & 3.35 & 1.482 \\
$\begin{array}{l}\text { Internet/website } \\
\text { Health worker(s) }\end{array}$ & 21.4 & 28.5 & 11.5 & 8.7 & 29.6 & 100 & 2.97 & 1.559 \\
$\begin{array}{l}\text { Seminar workshop } \\
\text { /conference }\end{array}$ & 16.9 & 30.0 & 12.5 & 15.8 & 24.5 & 100 & 3.01 & 1.46 \\
\hline
\end{tabular}

Table 3 shows the predominant channel in which Lagos residents heard about HIV/HBV con-infection. Of all the communication channels, television was predominantly utilised by $35.8 \%$ respondents in

Table 3 Respondents predominant channels for HIV/HBV information

\begin{tabular}{lr} 
Information sources & \% (n=200) \\
Television & 35.8 \\
Radio & 12.5 \\
Newspaper & 8.5 \\
Internet / Website & 10.8 \\
Friends & 9.1 \\
Colleagues & 2.8 \\
Relative & 1.1 \\
Spouse & 1.7 \\
Neighbors & .6 \\
Counselor & 1.1 \\
Health worker & 6.3 \\
Others & 9.7 \\
Total & 100.0 \\
& \\
\hline
\end{tabular}

The knowledge level of respondents of Lagos towards HIV/HBV co-infection is presented in Table 4. It sourcing information about the co-infection. This is followed by radio with $12.5 \%$ and internet mediated sources with $10.8 \%$ of the respondents.

shows that $60 \%$ of the respondents believe the coinfection is caused by a virus, $20.1 \%$ disagreed. On the effect of the co-infection on the proper functioning of liver, $49.4 \%$ noted that it does, $32.4 \%$ were undecided. In addition, $48.3 \%$ of the respondents believes in the capacity of the disease transmitting from a mother to her foetus, while $22.7 \%$ do not believe in its transmissibility. Again on transmission through the use of infected sharp objects, $63.9 \%$ believes in its possibility, while $23.3 \%$ were undecided and $12.8 \%$ disagreed. Furthermore, $44.9 \%$ of the respondents were not sure in ability of the co-infection in causing liver cancer, while $41.5 \%$ believes it can cause liver cancer. Respondents were further asked on the ability of a person being co-infected, $36.9 \%$ agree, while $36.9 \%$ were undecided. On the knowledge of respondent on transmission through sexual 
intercourse, $62.2 \%$ believes so, while $24.4 \%$ were not sure and $13.4 \%$ disagreed with this statement. An average of the sampled respondents strongly agreed to the existence of a vaccine to the co-infection, while, $33 \%$ were not sure and $16.8 \%$ do not agree to a vaccine existence for the co-infection
Table 4

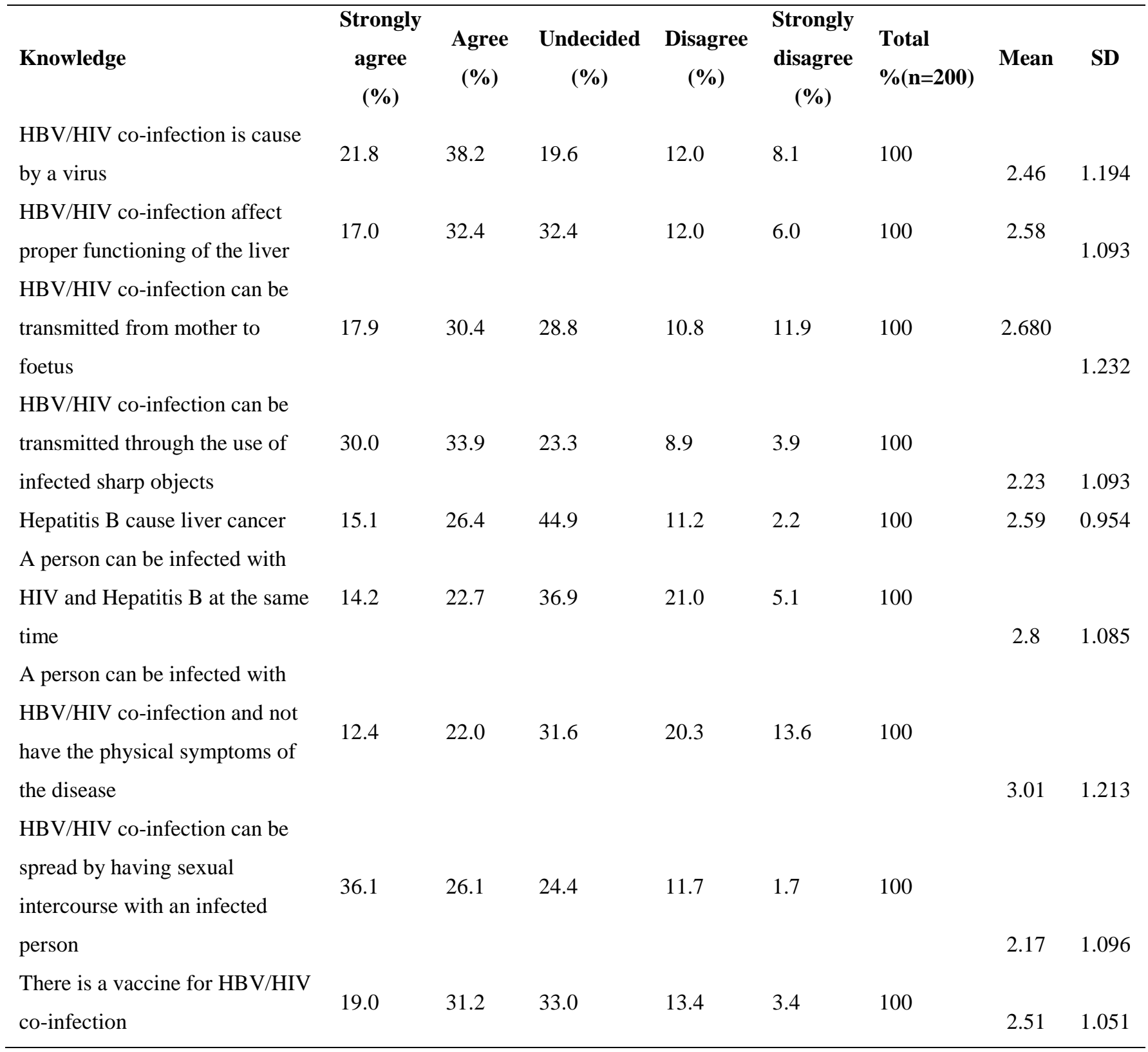

The attitude of the respondent towards HIV/HBV coinfection were examined in Table 5. While a little more than average representing $52.9 \%$ disagreed that they had no concern being infected, $25.3 \%$ declared they were not sure, $21.4 \%$ stated they were not concerned. Interestingly, when asked if they could be infected with HIV/HBV co-infection, $61.1 \%$ declared they cannot be infected, $22.3 \%$ were not sure, $16.6 \%$ 
stated they could be infected. Result of willingness of respondents to go for $\mathrm{HIV} / \mathrm{HBV}$ co-infection test, $48.5 \%$ noted they were not willing, 28.9 said they were not sure and $22.6 \%$ affirmed they were willing to go for a test. In addition, $52.6 \%$ of the sampled respondents declared they need to be protected against contracting $\mathrm{HIV} / \mathrm{HBV}$ co-infection, $26 \%$ were indecisive and 21.4 disagreed. Also, $43 \%$ of the respondent noted they would be afraid if they found out they had contracted the disease, $34.3 \%$ were uncertain and $23 \%$ said they would not exercise any fear. Respondents were further asked if they would engage in self-medication if they found out they had contracted the co-infection, $36.9 \%$ disagreed to this, $34.4 \%$ were not certain and 28.4 stated they would. Again $51.1 \%$ stated they would go to a health facility if they found they had contracted the disease, $33.5 \%$ were uncertain and $15.3 \%$ disagreed. In addition, $57 \%$ disagreed to the poser that they would go to a traditional healer if they found they had the symptoms of $\mathrm{HIV} / \mathrm{HBV}, 31.1 \%$ were not sure. Again, 53.2\% disagreed they would opt for spiritual healing, $31.4 \%$ were indecisive, $15.4 \%$ however noted they would go for spiritual healing. Also, 55.9\% of the respondents disagreed to the poser that they would do nothing if they found out they had the symptoms of the coinfection, $29.7 \%$ however were not certain. Furthermore, $34.9 \%$ of the respondents acknowledged that the fear of death would be their main concern if diagnosed with the co-infection, $33.2 \%$ disagreed with this and $32 \%$ were not sure. While $48.5 \%$ agreed to the poser that the fear of the disease spreading to their family members would be their main concern, $41.4 \%$ disclosed that the cost of treatment would be their main challenge if diagnosed with HIV/HBV coinfection.

Table 5

Respondents attitude towards HIV/HBV co-infection

\begin{tabular}{|c|c|c|c|c|c|c|c|c|}
\hline Attitude & $\begin{array}{c}\text { Strongly } \\
\text { agree } \\
(\%)\end{array}$ & $\begin{array}{c}\text { Agree } \\
(\%)\end{array}$ & $\begin{array}{l}\text { Undecided } \\
\qquad(\%)\end{array}$ & $\begin{array}{c}\text { Disagree } \\
(\%)\end{array}$ & $\begin{array}{c}\text { Strongly } \\
\text { disagree } \\
(\%)\end{array}$ & $\begin{array}{l}\text { Total } \\
\%(n=200)\end{array}$ & Mean & SD \\
\hline $\begin{array}{l}\text { I have no concern being infected } \\
\text { with } \mathrm{HBV} / \mathrm{HIV} \text { co-infection }\end{array}$ & 8.6 & 13.2 & 25.3 & 25.9 & 27.0 & 100 & 3.49 & 1.257 \\
\hline $\begin{array}{l}\text { I think I can be infected with } \\
\text { HBV/HIV co-infection }\end{array}$ & 2.9 & 13.7 & 22.3 & 15.4 & 45.7 & 100 & 3.87 & 1.216 \\
\hline $\begin{array}{l}\text { I would be willing to go for } \\
\text { HBV/HIV co-infection test }\end{array}$ & 5.8 & 16.8 & 28.9 & 23.1 & 25.4 & 100 & 3.46 & 1.203 \\
\hline $\begin{array}{l}\text { I need to be protected from } \\
\mathrm{HBV} / \mathrm{HIV} \text { co-infection }\end{array}$ & 27.7 & 24.9 & 26.0 & 12.7 & 8.7 & 100 & 2.5 & 1.26 \\
\hline $\begin{array}{l}\text { I would be afraid if I find out I had } \\
\text { HBV/HIV co-infection }\end{array}$ & 22.5 & 20.2 & 34.3 & 12.9 & 10.1 & 100 & 2.68 & 1.241 \\
\hline If I think I have symptoms of & & & & & & & & \\
\hline HBV/HIV co-infection I opt for & 14.2 & 14.2 & 34.7 & 15.9 & 21.0 & 100 & & \\
\hline self-medication & & & & & & & 3.15 & 1.302 \\
\hline
\end{tabular}


If I think I have symptoms of

HBV/HIV co-infection I will go to

21.6

29.5

33.5

10.2

5.1

2.48

1.095

If I think I have symptoms of

HBV/HIV co-infection I will go to

6.2

5.6

31.1

26.0

31.0

100

a traditional healer

If I think I have symptoms of

HBV/HIV co-infection I will go for 9

$\begin{array}{llllll}9.1 & 6.3 & 31.4 & 24.6 & 28.6 & 100\end{array}$

spiritual healing

24.6

If I think I have symptoms of

HBV/HIV co-infection I will do

$\begin{array}{lll}8.1 & 6.4 & 29.7\end{array}$

23.3

32.6

100

nothing

Fear of death would be my main

concern if I am diagnosed with

$\begin{array}{lll}14.3 & 20.6 & 32.0\end{array}$

18.3

14.9

100

HBV/HIV co-infection

Fear of disease spreading to family

members would be my main

concern if I am diagnosed with

$\begin{array}{lll}19.4 & 29.1 & 28.6\end{array}$

14.3

8.6

100

HBV/HIV co-infection

2.63

1.195

Cost of treatment would be my main concern if I am diagnosed

$\begin{array}{lll}15.3 & 26.1 & 30.1\end{array}$

18.2

10.2

100

with HBV/HIV co-infection

The study sought to find out the preventive practice of Lagos respondents towards HBV/HIV co-infection as presented in Table 6. Respondents were asked if they have been tested for the co-infection and a more than average representing, $55.5 \%$ noted they have not, while $26.8 \%$ declared they have. Respondents who ask for the usage of new syringe at health facility make up $51.4 \%$, while $24.3 \%$ were not sure, another $24.3 \%$ stated they do not request for a new syringe. Furthermore, $56.5 \%$ of the sampled respondents in Lagos declared that they often request a change the blade, needle as well as sterilize their clipper at the point of usage from their hair stylists. A total of $52 \%$ of the sampled population in Lagos State further stated that before they undergo any blood transfusion, they enquire if the blood has been screened, $27.4 \%$ however noted they were not sure $20.5 \%$ were in the negative to this poser. 
Respondents practice of HIV/HBV co-infection

\begin{tabular}{|c|c|c|c|c|c|c|c|c|}
\hline Selected variables & $\begin{array}{c}\text { Strongly } \\
\text { agree } \\
(\%)\end{array}$ & $\begin{array}{c}\text { Agree } \\
(\%)\end{array}$ & $\begin{array}{l}\text { Undecided } \\
\qquad \%)\end{array}$ & $\begin{array}{c}\text { Disagree } \\
(\%)\end{array}$ & $\begin{array}{c}\text { Strongly } \\
\text { disagree } \\
(\%)\end{array}$ & $\begin{array}{l}\text { Total } \\
\%(n=200)\end{array}$ & Mean & SD \\
\hline $\begin{array}{l}\text { I have been screened for HBV/HIV } \\
\text { co-infection before }\end{array}$ & 13.7 & 13.1 & 17.7 & 24.6 & 30.9 & 100 & 3.46 & 1.401 \\
\hline $\begin{array}{l}\text { I ask for a new syringe at health } \\
\text { facilities if you need to use one }\end{array}$ & 23.1 & 28.3 & 24.3 & 15.6 & 8.7 & 100 & 2.58 & 1.244 \\
\hline $\begin{array}{l}\text { I often ask my hair stylist to change } \\
\text { blade, needle or sterilize the clipper }\end{array}$ & 23.7 & 32.8 & 24.3 & 14.1 & 5.1 & 100 & 2.44 & 1.147 \\
\hline $\begin{array}{l}\text { I ask about screening of blood before } \\
\text { transfusion }\end{array}$ & 21.1 & 30.9 & 27.4 & 13.1 & 7.4 & 100 & 2.55 & 1.178 \\
\hline
\end{tabular}

\section{DISCUSSION}

The prevalence of HIV/HBV co-infection is of serious concern to the endemic area of Nigeria. Human Immunodeficiency Virus and Hepatitis B Virus coinfection have exacted a high morbidity and mortality rate in many parts of South-Western Nigeria. In aiming at achieving the Sustainable Development Goal 3:3 of ending hepatitis and HIV, it is necessary that people in these societies have access to information on these diseases. Thus, this data-based study examined how residents of Lages use information sources for HIV/HBV messages. The study revealed that television, radio and internetmediated sources are the predominant sources of information on HIV/HBV co-infection amongst Lagos residents. More specifically, television was found to be the most prevalent source of information on HIV/HBV co-infection, which is similar to previous studies that have noted the importance of television as a medium for disseminating information on public health [32]. However, seminars and workshops were discovered to be the least sought out source of information on the diseases. In essence, the traditional media of television and radio, as well as internet channels serve as potent information sources for health communication interventions (29). This aligns with the findings of Evaristus, et al. [17], Adesina, et al.
[20], which asserts that the media serves as health communication platforms for creating awareness of diseases in developing countries. It is further corroborated by the positions of Adesina, et al. [18], who maintained that information sources on health issues are key for low income regions . Therefore, information sources of traditional (newspapers, magazines, television, radio), new media (youtube, and social media) and interpersonal communication serve as veritable platforms to enlighten and educate people on HIV/HBV co-infection. The Diffusion of Innovation theory affirms this, as one of its tenets places information sources as pivotal means for diffusion of knowledge on health-related matters.

The study revealed that respondents have a fairly sufficient knowledge on HIV/HBV co-infection, which corroborates the findings of Eni, et al. [33], stating that most Nigerians showed an average level of knowledge on HBV. Another interesting discovery of this study is that quite a number of individuals are aware of HBV and HIV being transmitted through sharp objects and sexual intercourse. However, a significantly less amount does not believe in the transmission of these diseases from mother to foetus. This shows that there are still misconceptions on HIV/HBV co-infection amongst Lagos State residents. 
These misconceptions and gaps in knowledge of HBV and HIV were also found in a study conducted amongst healthcare workers in Malawi, as quite a number of them were not aware of the mother-foetus means of transmission [34]. The same applies to Vietnamese university students, as only 39.5\% know of the mother to child transmission [35]. Still on misconceptions, this study revealed that most respondents do not know of the possibility of an individual being infected with both HIV and HBV at the same time. Contrary to this, are the findings of Kye-Duodu, et al. [36], which shows that $84 \%$ of the health workers sampled in Ghana have adequate knowledge of the co-infection. Furthermore, only half of respondents in this study have knowledge on the existence of a vaccine for HIV/HBV co-infection, which is similar to a study by Eni, et al. [33], revealing that only $31.96 \%$ of respondents are aware of this vaccine. These findings depict that although, individuals generally have an average knowledge on these diseases, there is still a knowledge-gap in endemic areas of HIV/HBV co-infection. In another endemic area of China, a study done amongst pregnant women in Guangdong province revealed that there is a poor knowledge level of HBV. Some of them are not aware of the mother-foetus transmission, or the transmission through unprotected sex; and most of them do not know of HBV/HIV co-infection [37].

While there is dearth of research conducted on the attitudes of semi-urban and urban population towards HIV/HBV co-infection, such as this study, most studies on KAP have been done among health care workers. Most respondents show a slightly positive attitude towards treatment and protection from HBV/HIV co-infection. This is in line with a study done on medicine and health science students in University of Gondar, Ethiopia, which found that about $75 \%$ of them have a good attitude towards the treatment and control of $\mathrm{HBV}$; and $82.1 \%$ have no issue with treating HBV-positive patients [38]. In another study, it was discovered that $67.8 \%$ of healthcare workers in Cameroon have a positive attitude towards HBV-positive patients [39]. On the contrary, a study done on the attitudes of dentists towards patients with these diseases, was found to be negative; with $73 \%$ of dentists not being willing to treat patients who are HIV-positive [40]. An eyeopening study conducted by Dahlström and Funegård Viberg [35], revealed the relationship that exists between knowledge and attitudes. Participants who had a higher knowledge of the infection were more likely to have received the HBV vaccination, or be screened. Mtengezo, et al. [34] in a study conducted among 194 health care workers shows that the workers are adequately informed of the co-infection, and thus, have a positive attitude about it. This could explain why in this study, the respondents who are not aware of HIV/HBV co-infection causing liver cancer, is slightly proportionate to the percentage of respondents who claim they would not fear if they found out they HIV/HBV co-infection. They are ignorant of the gravity of this infection and thus, are not willing to take preventive measures. Similarly, it was revealed that most respondents did not think they could be infected with this virus and were not willing to go for a co-infection test. This was the case in a study conducted by Ella [41] on midwives in University of Calabar Teaching Hospital, Nigeria; which shows that there is still some level of inadequate knowledge, as most interns who had not been vaccinated decided against it because they felt they had been extremely cautious in handling infected patients and thus, did not need the vaccine. It was also discovered that Lagos residents, fear the cost of HBV/HIV co-infection 
treatment more than they fear the possibility of death due to the co-infection. This aligns with Akazong, et al. [39] who stated that a reason for the negative attitude of some healthcare workers towards HBV patients could be due to the vaccine being costly.

The results of this study revealed only an average of Lagos State residents take preventive measures against HIV/HBV co-infection. The slightly average knowledge on the co-infection could attribute to the equally average practice measures taken by respondents, as asserted in a study by Akazong, et al. [39], stating that the insufficient knowledge might justify the low frequency of vaccinations amongst healthcare workers. These findings are also supported by another study which shows that there is an existing relationship between knowledge and practice measures. Thus, a higher knowledge level implies higher preventive practice measures, and vice versa [41, 42]. A study conducted by Mustafa, et al. [43] revealed that there is a positive correlation between vaccination among health workers, and their knowledge, attitude and practice towards HBV. In this study, most respondents show an average knowledge and attitude towards HBV, which aligns with the average practice measures of screening and safety measures in using sharp objects like blades and syringes. Adherence to practice measures has been recorded to be higher in medical professionals [40, 41, $44,45]$ by wearing protective masks, gloves and gowns, washing of hands, sterilizing instruments, amongst others. On the contrary, Abdela, et al. [38] revealed that medical students engaged risky practice measures, as some of them do not report needle-stick injury, which can expose them to HBV infection. Also, most of them have never been screened $(90.7 \%)$ or gotten a vaccination $(95.1 \%)$ for HBV. These results are similar to that of Okeke, et al. [46] which shows the low level of preventive measures such as vaccinations, despite the prevalence of needle-stick injuries amongst medical students in Jos University Teaching Hospital, Nigeria. In another study on dental surgeons in the University of Benin Teaching Hospital, Nigeria, it was revealed that $64 \%$ of dental surgeons did not take PEP (Post-exposure Prophylaxis) after exposure to the risk of HIV/HBV co-infection [47]. This present study shows that there's an average preventive practice of HIV/HBV among Lagos residents, and these findings are similar to previous ones which show average level of precautionary techniques by hairdressers and barbers through reusing razors, non-sterilization, lack of disinfection, lack of vaccination, lack of washing hands, lack of protective gear such as gloves, amongst others [48-50].

\section{CONCLUSION AND RECOMMENDATIONS}

Despite the increase prevalence of HIV/HBV is much in Nigeria, the study shows a rather average knowledge on the disease by the citizens. The traditional media of television and radio contributed to this outcome. Harnessing all communication channels of traditional, online as well as interpersonal networks would therefore play a fundamental role in awareness creation and adoption of positive behavioral practice for the disease management. If the people are adequately informed through channels: television, social media, workshop/conferences, it will go a long way, not only, to prevent the co-infection but to reduce the percentage of fear in people. Such integrated system of communication if adopted would engender the vision of eliminating either the mono-infection or co-infection of $\mathrm{HBV}$ and $\mathrm{HIV}$ as contained in Sustainable Development Goal 3. Salient actions to enforce the need for vaccination and other preventive 
measures are highly recommended for implementation

by governmental and non-governmental agencies. The study further recommends that salient actions to enforce the need for vaccination and other preventive measures are highly recommended for implementation by governmental and non-governmental agencies.

\section{CONFLICT OF INTEREST}

We declare no conflict of interest

\section{References}

[1] P. Howden-Chapman, J. Siri, E. Chisholm, R. Chapman, C. N. Doll, and A. Capon, "SDG 3: Ensure healthy lives and promote wellbeing for all at all ages," A guide to SDG interactions: from science to implementation. Paris, France: International Council for Science, pp. 81-126, 2017.

[2] M. Ringehan, J. A. McKeating, and U. Protzer, "Viral hepatitis and liver cancer," Philosophical Transactions of the Royal Society B: Biological Sciences, vol. 372, no. 1732, p. 20160274, 2017.

[3] WHO, "GLOBAL HEPATITIS REPORT, 2017," 2017.

[4] WHO, "World Health Organization Hepatitis B Fact Sheet," 2015. World Health Organization: Geneva.

[5] K. Niizuma, Y. Ogawa, T. Kogure, and T. Tominaga, "Case reports of latent HBV hepatitis in patients after neurosurgical treatment for hypothalamic and pituitary tumors," $B M C$ Infectious Diseases, vol. 20, no. 1, pp. 1-7, 2020.

[6] C. S. Hyun, O. Ko, S. Lee, and J. McMenamin, "Long term outcome of a community-based hepatitis B awareness campaign: eight-year follow-up on linkage to care (LTC) in HBV infected individuals," BMC infectious diseases, vol. 19 , no. 1, p. 638, 2019.

[7] M. Puoti et al., "Hepatitis B virus co-infection in human immunodeficiency virus-infected subjects," AIDS rev, vol. 4, no. 1, pp. 27-35, 2002.

[8] H.-Y. Sun, W.-H. Sheng, M.-S. Tsai, K.-Y. Lee, S.-Y. Chang, and C.-C. Hung, "Hepatitis B virus coinfection in human immunodeficiency virusinfected patients: a review," World journal of gastroenterology: WJG, vol. 20, no. 40, p. 14598, 2014.

[9] M. J. Alter, "Epidemiology of viral hepatitis and HIV co-infection," Journal of hepatology, vol. 44, pp. S6-S9, 2006.

[10] S. I. Tumpa and A. Al Mamun, "HIV/HBV Coinfection-A Global Challenge," Bangladesh Journal of Medical Science, vol. 14, no. 4, pp. 316-322, 2015.

\section{SOURCE OF FUNDING}

The Covenant University Centre for Research, Innovation and Development (CUCRID) provided fund for collation of the data that was used for this study

\section{ACKNOWLEDGEMENT}

We appreciate the Covenant University Centre for Research, Innovation and Discovery (CUCRID) for the financial support for this publication.

C. L. Thio, "Hepatitis B and human immunodeficiency virus coinfection," Hepatology, vol. 49, no. S5, 2009.

[12] G. Ndow et al., "Hepatitis B testing and treatment in HIV patients in The Gambia-Compliance with international guidelines and clinical outcomes," PloS one, vol. 12, no. 6, p. e0179025, 2017.

[13] WHO, Consolidated guidelines on HIV prevention, diagnosis, treatment and care for key populations-2016 update. World Health Organization, 2016.

[14] A. B. Kharsany and Q. A. Karim, "HIV infection and AIDS in Sub-Saharan Africa: current status, challenges and opportunities," The open AIDS journal, vol. 10, p. 34, 2016.

[15] B. G. Williams and R. Granich, "Ending AIDS: trends in the incidence of HIV in eastern and southern Africa," bioRxiv, p. 383372, 2018.

[16] G. L. Kreps and R. Sivaram, "Strategic health communication across the continuum of breast cancer care in limited-resource countries," Cancer, vol. 113, no. S8, pp. 2331-2337, 2008.

[17] A. Evaristus, O. Olusola, O. Nelson, A. Lanre, A Babatunde, and Y. Darlynton, "Data on information sources, knowledge and practice on Hepatitis b virus in Southwest Nigeria," Data in brief, 2020, doi: doi.org/10.1016/j.dib.2020.105507.

[18] E. Adesina, O. Oyero, N. Okorie, O. Omojola, L. Amodu, and B. Adeyeye, "Health management strategies for hepatitis care practices: An interplay of communication structures and social marketing theory," in 32nd International Business Information Management Association Conference, ville, Spain, 2018, pp. 7305 -7309.

[19] E. Adesina, O. Oyero, N. Okorie, C. BenEnukora, and B. Adeyeye, "Risk communication for viral hepatitis management among migrants," in Handbook of Research on the Global Impact of Media on Migration Issues: IGI Global, 2020, pp. 235-252.

[20] E. Adesina et al., "Assessment of health communication practice on hepatitis B in Southwest Nigeria," Cogent Social Sciences, vol. 
6, no. 1, p. 1777814, 2020, doi: https://doi.org/10.1080/23311886.2020.1777814.

[21] D. Smith, "Health care consumer's use and trust of health information sources," Journal of Communication in Healthcare, vol. 4, no. 3, pp. 200-210, 2011.

[22] D. Yartey, O. Omojola, L. Amodu, N. Ndubueze, B. Adeyeye, and E. Adesina, "Personal data collection and usage for mobile marketing. Customer awareness and perception," WSEAS TRANSACTIONS on BUSINESS and ECONOMICS, vol. 18, 2020.

[23] S. Usaini, O. Nelson, O. Bamgboye, L. Amodu, F. Afolabi, and A. Evaristus, "Internet, social media and computer-mediated relationship among engineering undergraduate students," International Journal of Civil Engineering and Technology, vol. 9, no. 13, pp. 1651-1657, 2018.

[24] L. Amodu, O. Omojola, N. Okorie, B. Adeyeye, and E. Adesina, "Potentials of Internet of Things for effective public relations activities: Are professionals ready?," Cogent Business \& Management, vol. 6, no. 1, p. 1683951, 2019.

[25] Okeke, I. Egbuonu, E. Ugochukwu, T. Ulasi, and C. Okani, "Seroprevalence of HBV and HIV CoInfection in Children in Nnewi, South-East Nigeria," Ped Health Res, vol. 2, no. 3, p. 20, 2017.

[26] C. Ojide, E. Kalu, E. Ogbaini-Emevon, and V. Nwadike, "Co-infections of hepatitis B and C with human immunodeficiency virus among adult patients attending human immunodeficiency virus outpatients clinic in Benin City, Nigeria," Nigerian journal of clinical practice, vol. 18, no. 4, pp. 516-521, 2015.

[27] L. Owolabi et al., "Prevalence and Burden of Human Immunodeficiency Virus and Hepatitis B Virus Co-infection in Nigeria: A Systematic Review and Meta-Analysis," J AIDS Clin Res, vol. 5, no. 308, p. 2, 2014.

[28] P. Lar, V. Pam, P. Christopher, L. Gwamzhi, and J. Mawak, "Prevalence and immune status of HIV/HBV co-infected pregnant women," African Journal of Clinical and Experimental Microbiology, vol. 14, no. 3, pp. 120-126, 2013.

[29] O. Aluko, "The effects of location and neighbourhood attributes on housing values in metropolitan Lagos," Ethiopian Journal of Environmental Studies and Management, vol. 4, no. 2, pp. 69-82, 2011.

[30] P. Edewor, Y. A. Aluko, and S. F. Folarin, "Managing Ethnic and cultural diversity for national integration in Nigeria," Developing Country Studies, vol. 4, no. 6, pp. 70-76, 2014.

[31] G. O. Anetor and M. F. Oyekan-Thomas, "Knowledge and attitude of youths to substance abuse in Alimosho Local Government area of Lagos State," International Journal of Biological and Chemical Sciences, vol. 12, no. 2, pp. 822836, 2018.

[32] J. Burzyńska, M. Binkowska-Bury, and P. Januszewicz, "Television as a source of information on health and illness-review of benefits and problems," Progress in Health Sciences, vol. 5, no. 2, pp. 174-184, 2015.

[33] A. O. Eni, M. G. Soluade, O. O. Oshamika, O. P. Efekemo, T. T. Igwe, and O. A. Onile-ere, "Knowledge and Awareness of Hepatitis B Virus Infection in Nigeria," Annals of global health, vol. 85, no. 1, 2019.

[34] J. Mtengezo et al., "Knowledge and attitudes toward HIV, hepatitis B virus, and hepatitis C virus infection among health-care workers in Malawi," Asia-Pacific journal of oncology nursing, vol. 3, no. 4, p. 344, 2016.

[35] E. Dahlström and E. Funegård Viberg, "Knowledge about hepatitis B virus infection and attitudes towards hepatitis B virus vaccination among Vietnamese university students in Ho Chi Minh City:-A quantitative study," ed, 2013.

[36] G. Kye-Duodu et al., "Prevalence of hepatitis B virus co-infection among HIV-seropositive persons attending antiretroviral clinics in the Eastern Region of Ghana," The Pan African medical journal, vol. 25, no. Suppl 1, 2016.

[37] Y. Ruan et al., "Incidence of HIV, hepatitis C and hepatitis B viruses among injection drug users in southwestern China: a 3-year follow-up study," Aids, vol. 21, pp. S39-S46, 2007.

[38] A. Abdela, B. Woldu, K. Haile, B. Mathewos, and T. Deressa, "Assessment of knowledge, attitudes and practices toward prevention of hepatitis B virus infection among students of medicine and health sciences in Northwest Ethiopia," BMC research notes, vol. 9, no. 1, p. 410, 2016.

[39] E. Akazong, C. Tume, R. Njouom, L. Ayong, V. Fondoh, and J.-R. Kuiate, "Knowledge, attitude and prevalence of hepatitis B virus among healthcare workers: a cross-sectional, hospitalbased study in Bamenda Health District, NWR, Cameroon," BMJ open, vol. 10, no. 3, p. e031075, 2020.

[40] H. Kadeh, S. Saravani, and P. Golzari, "Knowledge, attitude and practice of dentists towards patients with HIV, Hepatitis B and Hepatitis C infections," 2014.

[41] R. E. Ella, "Knowledge and Practice for Prevention of Hepatitis B among Practicing Midwives in University of Calabar Teaching Hospital, Calabar Nigeria."

[42] E. Adesina, O. Omojola, A. Babatunde, L. Amodu, and D. Yartey, "Menace of waste dumping along median strips and drainage in Ogun state: a development communication approach," WSEAS Tansaction on Environment and Development vol. 17, 2021.

[43] A. S. M. Mustafa et al., "Knowledge, attitude and practice of hepatitis (B) among healthcare workers in relation to their vaccination status in Khartoum, Sudan, 2015: a cross-sectional study," Sudan Journal of Medical Sciences, vol. 13, no. 1, pp. 22-32, 2018. 
[44] M. Askarian, K. Mirzaei, and B. Cookson, "Knowledge, attitudes, and practice of Iranian dentists with regard to HIV-related disease," Infection Control \& Hospital Epidemiology, vol. 28, no. 1, pp. 83-87, 2007.

[45] E. Adesina, D. Adeloye, H. Falola, B. Adeyeye, D. Yartey, and T. Kayode-Adedeji, "Health communication and behavioural practice towards ending Hepatitis B Virus in Southwest Nigeria," The Scientific World Journal, vol. 2020, 2020.

[46] E. Okeke, N. Ladep, E. Agaba, and A. Malu, "Hepatitis B vaccination status and needle stick injuries among medical students in a Nigerian university," Niger J Med, vol. 17, no. 3, pp. 3302, 2008.

[47] M. Okoh and B. D. Saheeb, "Assessment of knowledge, attitude and practice of post-exposure prophylaxis against blood-borne viral infection among dental surgeons in a teaching hospital," Southern African Journal of Infectious Diseases, vol. 32, no. 1, pp. 17-22, 2017.
[48] E. Amodio, M. A. Di Benedetto, L. Gennaro, C. M. Maida, and N. Romano, "Knowledge, attitudes and risk of HIV, HBV and HCV infections in hairdressers of Palermo city (South Italy)," European journal of public health, vol. 20, no. 4, pp. 433-437, 2010.

[49] A. Jokhio, T. Bhatti, and M. Memon, "Knowledge, attitudes and practices of barbers about hepatitis B and C transmission in Hyderabad, Pakistan," EMHJ-Eastern Mediterranean Health Journal, 16 (10), 10791084, 2010, 2010.

[50] B. Adeyeye, L. Amodu, O. Odiboh, K. Oyesomi, E. Adesina, and D. Yartey, "Agricultural Radio Programmes in Indigenous Languages and Agricultural Productivity in North-Central Nigeria," Sustainability, vol. 13, no. 7, p. 3929, 2021.

\section{Creative Commons Attribution License 4.0 (Attribution 4.0 International, CC BY 4.0)}

This article is published under the terms of the Creative Commons Attribution License 4.0

https://creativecommons.org/licenses/by/4.0/deed.en_US 